\section{Discussion}

Diazepam has been shown to have sedative, muscle relaxant, and anticonvulsant properties. The intravenous administration of $5-15 \mathrm{mg}$ in a variety of non-hepatic disorders is safe and without clinically significant haemodynamic, respiratory, or metabolic changes. Recovery is usually complete within 90 minutes of its administration (Healy et al., 1970). Study of the disappearance curve of diazepam from the blood after oral and parenteral administration (Schwartz et al., 1965; de Silva et al., 1966) indicates rapid and extensive uptake by tissues with an overall drug half-life of two to three days, and if $30 \mathrm{mg}$ orally is given daily there is a progressive increase in plasma diazepam levels (de Silva et al., 1966). In keeping with this are the effects of diazepam on the E.E.G. which may take some days to develop fully during continued administration and may persist for some days after discontinuation of the drug (Towler et al., 1962; Metcalfe and Whitley, 1964). The main change in the E.E.G. observed in normal subjects is the apbearance of low to moderate voltage fast activity first in the frontal areas and spreading posteriorly with a reduction in amplitude of normal alpha rhythm.

Though the major site of metabolic breakdown of diazepam by demethylation, hydroxylation, and conjugation is in the liver, the response of our patients with liver disease does not differ from that reported for normal subjects (Healy et al., 1970). In particular drowsiness was not prolonged or exaggerated even in those with hepatic encephalopathy. A reduction in E.E.G. dominant frequency and an increase in slow-wave activity give some index of the severity of liver disease (Laidlaw and Read, 1963), and our patients with hevatic encephalopathy either in the vast or at the time of study showed the most pronounced E.E.G. changes. Even in these patients, however, there was no tendency to develop increased slow activity in the E.E.G. as has been described after morphine or chlorpromazine.
The results of present studies show that a single injection of $5 \mathrm{mg}$ of diazepam is safe when assessed both clinically and by serial E.E.G. recordings in a group of patients with relatively well compensated chronic liver disease. We have also had some clinical experience of it in patients with fulminant hepatic failure. It can be of value in controlling the epileptic convulsions that these patients so often have. A dose of $5 \mathrm{mg}$ intravenously given slowly over 10 minutes is sufficient on most occasions, but this dosage may be repeated after 30 minutes and then up to four-hourly. With such a regimen we have sometimes observed depression of respiration-a hazard to which these patients are particularly prone-and careful monitoring is essential.

We are grateful to Dr. K. J. Zilkha for his support and to Mrs. $M$. Roome for valuable technical help. The King's College Hospital Research Trust gave generous financial support.

\section{References}

de Silva, J. A., Koechlin, B. A., and Bader, G. (1966). Fournal of Pharmaceutical Sciences, 55, 692.

Healy, T. E. J., Robinson, J. S., and Vickers, M. D. (1970). British Medical

Laidlaw, J., and Aitken, R. (1966). Electroencephalography and Clinical Neurophysiology, 21, 202.

Laidlaw, J., and Read, A. E. (1963). Clinical Science, 24, 109.

Laidlaw, J., Read, A. E., and Sherlock, S. (1961). Gastroenterology, 40, 389. Metcalf, D. R., and Whitley, D. J. (1964). American fournal of Psychiatry, $120,1114$.

Parkes, J. D., Murray-Lyon, I. M., and Williams, R. (1970). Quarterly Fournal of Medicine, 39; 515

Read, A. E., Laidlaw, J., and McCarthy, C. F. (1969). British Medical fournal, 3, 497.

Schwartz, M. A., Koechlin, B. A., Postma, E., Palmer, S., and Krol, G. (1965). Fournal of Pharmacology and Experimental Therapeutics, 149, 423. Towler, M. L., Beall, B. D., and King, J. B. (1962). Southern Medical fournal, 55, 832. Trey, C., Burns, D. G., and Saunders, S. J. (1966). New England fournal of

\title{
Use of Metolazone in the Treatment of Ascites due to Liver Disease
}

\author{
P. HILLENBRAND, SHEILA SHERLOCK
}

British Medical fournal, 1971, 4, 266-270

\section{Summary}

In 8 out of 20 patients with chronic liver disease ascites was controlled with metolazone, 10 required additional amiloride or spironolactone to achieve control, and 2 were resistant to all diuretic therapy. An initial dose of $5 \mathrm{mg}$ daily is suggested, though much higher doses may be required ultimately. When metolazone is used alone the high incidence of hypokalaemia $(80 \%)$, hypochloraemia (35\%), and encephalopathy (35\%) compared with the results of other series is a major disadvantage and indicates that this drug should be used with caution in patients with liver disease. Hypokalaemia can usually be prevented by the simultaneous administration of amiloride or spironolactone. The low incidence of azotaemia (5\%) suggests that this diuretic may be useful if renal function is particularly impaired.

Department of Medicine, Royal Free Hospital, London WC1X 8LF P. HILLENBRAND, M.R.C.P., Honorary Assistant Lecturer SHEILA SHERLOCK, M.D., F.R.C.P. (LOND., ED.), Professor of Medicine

\section{Introduction}

Metolazone is a quinazolinone diuretic, chemically related to quinethazone. Its action resembles that of thiazides, though animal experiments indicate that it is more potent and less kaliuretic. Diuresis begins within two hours and persists for 24 hours in normal subjects. Dose-response studies in normal subjects show that a maximum diuretic activity is observed on raising the dose to $10 \mathrm{mg}$. The purpose of this study was to determine the efficacy of metolazone in controlling ascites due to liver disease and to assess the incidence of complications, particularly electrolyte disturbance.

\section{Patients and Methods}

Twenty patients with chronic liver disease and persistent ascites were studied (Table I). They were put to bed, weighed daily, and given a $22-\mathrm{mEq}$ sodium diet. Fluid intake was restricted to $1,000 \mathrm{ml}$ a day. Protein intake was $60-70 \mathrm{~g}$ except during episodes of encephalopathy. Fluid intake and output and 24-hour urine sodium, potassium, and chloride were measured. Blood urea, electrolytes liver function tests, 
TABLE I-Metolazone Trial: Drug Therapy and Control of Ascites

\begin{tabular}{|c|c|c|c|c|c|c|c|}
\hline $\begin{array}{l}\text { Case } \\
\text { No. }\end{array}$ & Age & Sex & $\begin{array}{l}\text { Aetiology of } \\
\text { Liver Disease }\end{array}$ & Diuretics & $\underset{(\mathrm{mEq} / \text { day })}{\mathrm{KCl} \text { Supplement }}$ & $\begin{array}{l}\text { Control of } \\
\text { Ascites }\end{array}$ & Comment \\
\hline 1 & 38 & M. & $\begin{array}{l}\text { Cryptogenic cirrhosis } \\
\text { (active) }\end{array}$ & $\begin{array}{l}\text { Metolazone } 50 \mathrm{mg} \text { every } \\
\text { 3rd day. Amiloride } 10 \\
\text { mg alternate days }\end{array}$ & $50-160$ & Yes & $\begin{array}{l}\text { Large diuresis and pronounced hypokalaemia after first dose } \\
(50 \mathrm{mg}) \text { of metolazone. Hypokalaemia not corrected by } \\
\text { amiloride. Died six months later }\end{array}$ \\
\hline 2 & 55 & M. & Alcoholic cirrhosis & $\begin{array}{l}\text { mg alternate days } \\
\text { Metolazone } 150 \mathrm{mg} \text { daily. } \\
\text { Amiloride } 10 \mathrm{mg} \text { daily }\end{array}$ & $50-160$ & No & Resistant to diuretics. Hepatocellular failure. Recurrent \\
\hline 3 & 57 & F. & Cirrhosis (post-viral) & Metolazone $150 \mathrm{mg}$ daily. & $80-220$ & Yes & $\begin{array}{l}\text { haemorrhage rather than to diuretics. Died } 2 \text { months later } \\
\text { Hypokalaemia a problem despite addition of amiloride }\end{array}$ \\
\hline 4 & 56 & F. & Primary biliary cirrhosis & $\begin{array}{l}\text { Metolazone } 50 \mathrm{mg} \text { (one } \\
\text { dose only) }\end{array}$ & $50-220$ & Yes & $\begin{array}{l}\text { Large diuresis after metolazone, } 50 \mathrm{mg} \text {, with hypokalaemia } \\
\text { and precoma. Gastrointestinal haemorrhage and renal failure. } \\
\text { Died } 2 \text { weeks later }\end{array}$ \\
\hline 5 & 53 & F. & Alcoholic liver disease & $\begin{array}{l}\text { Metolazone } 150 \mathrm{mg} \text { daily. } \\
\text { Amiloride } 10 \mathrm{mg} \text { daily. } \\
\text { Spironolactone } 200 \mathrm{mg} \\
\text { daily for } 2 \text { weeks }\end{array}$ & $80-200$ & Yes & Amiloride, then spironolactone, added to induce diuresis \\
\hline 6 & 45 & M. & $\begin{array}{l}\text { Active chronic hepatitis } \\
+ \text { cirrhosis }\end{array}$ & $\begin{array}{l}\text { Metolazone } 25 \mathrm{mg} \text { daily. } \\
\text { Amiloride } 10 \mathrm{mg} \text { daily }\end{array}$ & $120-150$ & Yes & $\begin{array}{l}\text { Amiloride added to correct hypokalaemia. Patient bled from } \\
\text { oesophageal varices. Cause of leucopenia uncertain. ?Hyper- } \\
\text { splenism. ?Drugs. (Patient was on metolazone and amiloride) }\end{array}$ \\
\hline 7 & 59 & M. & $\begin{array}{l}\text { Alcoholic hepatitis }+ \\
\text { fibrosis }\end{array}$ & Metolazone $25 \mathrm{mg}$ daily & $40-200$ & Yes & $\begin{array}{l}\text { splensm. ?Drugs. (Patient was on metolazone and amiloride) } \\
\text { Good diuresis. No electrolyte imbalance }\end{array}$ \\
\hline 8 & 60 & F. & Alcoholic cirrhosis & $\begin{array}{l}\text { Metolazone } 10-25 \mathrm{mg} \\
\text { daily. Amiloride } 10 \mathrm{mg} \\
\text { daily }\end{array}$ & $100-160$ & Yes & $\begin{array}{l}\text { Amiloride added to correct hypokalaemia. Diuretic therapy } \\
\text { stopped because of encephalopathy. Patient died } 3 \text { weeks } \\
\text { later from cardiac infarct }\end{array}$ \\
\hline 9 & 26 & M. & Budd-Chiari syndrome & $\begin{array}{l}\text { Metolazone } 150 \mathrm{mg} \text { daily. } \\
\text { Amiloride } 10 \mathrm{mg} \text { daily. } \\
\text { Spironolactone } 200 \mathrm{mg} \\
\text { daily }\end{array}$ & $40-200$ & No & Resistent to diuretics. Died within one year \\
\hline 10 & 46 & M. & Cryptogenic cirrhosis & $\begin{array}{l}\text { Metolazone } 100 \mathrm{mg} \text { daily. } \\
\text { Amiloride } 10 \mathrm{mg} \text { (2 days } \\
\text { only) }\end{array}$ & $130-200$ & Yes & $\begin{array}{l}\text { Moderate diuresis on metolazone, with grade I encephalopathy. } \\
\text { Addition of amiloride resulted in grade III encephalopathy }\end{array}$ \\
\hline 11 & 60 & M. & $\begin{array}{l}\text { Active chronic hepatitis } \\
+ \text { cirrhosis }\end{array}$ & $\begin{array}{l}\text { Metolazone } 25 \mathrm{mg} \text { every } \\
\text { third day }\end{array}$ & $130-160$ & Yes & $\begin{array}{l}\text { Good diuresis. No electrolyte imbalance. Died one year later } \\
\text { from gastronitestinal haemorrhage }\end{array}$ \\
\hline 12 & .58 & M. & Cryptogenic cirrhosis & $\begin{array}{l}\text { Metolazone } 150 \mathrm{mg} \text { daily. } \\
\text { Amiloride } 10 \mathrm{mg} \text { daily }\end{array}$ & $100-160$ & Yes & Amiloride added to induce diuresis \\
\hline 13 & 21 & M. & $\begin{array}{l}\text { Cirrhosis (HAA positive) } \\
\text { hepatoma }\end{array}$ & $\begin{array}{l}\text { Metolazone } 5 \mathrm{mg} \text { every } \\
\text { 3-4 days }\end{array}$ & $80-230$ & Yes & $\begin{array}{l}\text { Good diuresis but recurrent electrolyte imbalance on small } \\
\text { dose of metolazone. Died within } 6 \text { weeks (pneumonia) }\end{array}$ \\
\hline 14 & 39 & M. & Alcoholic cirrhosis & $\begin{array}{l}\text { Metolazone } 25 \mathrm{mg} \text { every } \\
4-5 \text { days }\end{array}$ & 100 & Yes & Good diuresis. No electrolyte imbalance \\
\hline $\begin{array}{l}15 \\
16\end{array}$ & $\begin{array}{l}51 \\
34\end{array}$ & $\begin{array}{l}\text { M. } \\
\text { M. }\end{array}$ & $\begin{array}{l}\text { Alcoholic cirrhosis } \\
\text { Alcoholic liver disease }\end{array}$ & $\begin{array}{l}\text { Metolazone } 75 \mathrm{mg} \text { daily } \\
\text { Setolazone } 150 \mathrm{mg} \text { daily. } \\
\text { Spironolactone } 200 \mathrm{mg} \\
\text { daily }\end{array}$ & $\begin{array}{l}50-100 \\
50-130\end{array}$ & $\begin{array}{l}\text { Yes } \\
\text { Yes }\end{array}$ & $\begin{array}{l}\text { Good diuresis, but pronounced hypokalaemia } \\
\text { Spironolactone added to induce diuresis }\end{array}$ \\
\hline 17 & 45 & M. & $\begin{array}{l}\text { Cryptogenic cirrhosis } \\
\text { (active) }\end{array}$ & Metolazone $1 \mathrm{mg}$ daily & $80-200$ & Yes & $\begin{array}{l}\text { Large diuresis and hypokalaemia on metolazone, } 1 \mathrm{mg} \text { daily. } \\
\text { Died within six months }\end{array}$ \\
\hline $\begin{array}{l}18 \\
19\end{array}$ & $\begin{array}{l}51 \\
28\end{array}$ & $\begin{array}{l}M \\
M\end{array}$ & $\begin{array}{l}\text { Cirrhosis (post-viral) } \\
\text { Active chronic hepatitis }\end{array}$ & $\begin{array}{l}\text { Metolazone } 15 \mathrm{mg} \text { daily } \\
\text { Metolazone } 150 \mathrm{mg} \text { daily. } \\
\text { Spironolactone } 200 \mathrm{mg} \\
\text { daily }\end{array}$ & $\begin{array}{l}40-100 \\
80-160\end{array}$ & $\begin{array}{l}\text { Yes } \\
\text { Yes }\end{array}$ & $\begin{array}{l}\text { Good diuresis. Hypokalaemia } \\
\text { Spironolactone added to induce diuresis }\end{array}$ \\
\hline 20 & 56 & F. & Cryptogenic cirrhosis & $\begin{array}{l}\text { Metolazone } 150 \mathrm{mg} \text { daily. } \\
\text { Spironolactone } 200 \mathrm{mg} \\
\text { daily }\end{array}$ & 100 & Yes & Spironolactone added to induce diuresis \\
\hline
\end{tabular}

and full blood count were performed before and during treatment. Urea and electrolytes were measured at least twice a week.

Abdominal paracentesis was performed only as a diagnostic measure. Potassium chloride (Kloref) $50-200 \mathrm{mEq}$ daily was administered to all patients according to their needs. Diuretic therapy was started only after a four-day period of fluid and salt restriction and bed-rest had failed to induce a diuresis. No attempt was made to clear the ascites entirely.

Metolazone was administered in variable dosage according to response. Dosage ranged from 1 to $150 \mathrm{mg}$ daily. Potassium-sparing diuretics (amiloride $10-20 \mathrm{mg}$ daily or spironolactone $100-200 \mathrm{mg}$ daily) were added when necessary.

\section{Results}

In 8 out of 20 patients (Cases $4,7,11,13,14,15,17$, and 18) ascites was controlled with metolazone only (Table I). Three others (Cases 1, 6, and 8) had a brisk diuretic response to metolazone but amiloride was required to correct hypokalaemia. The remaining nine patients required additional amiloride or spironolactone in order to induce a diuresis, which was achieved in seven of them. Ascites was controlled - that is greatly reduced-in 18 of the 20 patients using metolazone with or without a potassium-sparing diuretic (Table 1).

Two patients failed to respond to metolazone with potassium-sparing diuretics. The first (Case 2) was an alcoholic cirrhotic with bleeding oesophageal varices, renal failure, and portal-systemic encephalopathy. $\mathrm{He}$ was withdrawn from the trial and died one month later. The second patient (Case 9), with the Budd-Chiari syndrome, was resistant to a com- bination of metolazone, spironolactone, ethacrynic acid, and prednisone. He died within a year.

An initial dosage of $50 \mathrm{mg}$ of metolazone was used in the first five patients and was found to be too high in two (Cases 1 and 4), both had a 3-litre diuresis, developed pronounced hypokalaemia, and lost more than $2 \mathrm{~kg}$ of body weight. Subsequent initial dosage levels were $25 \mathrm{mg}$ in 11 patients and $5 \mathrm{mg}$ in the last four patients in the trial.

Of the 18 patients whose ascites was controlled, eight responded initially to metolazone at a dosage of $25 \mathrm{mg}$ or less, and four of these had a diuresis on $10 \mathrm{mg}$ or less (Fig. 1).

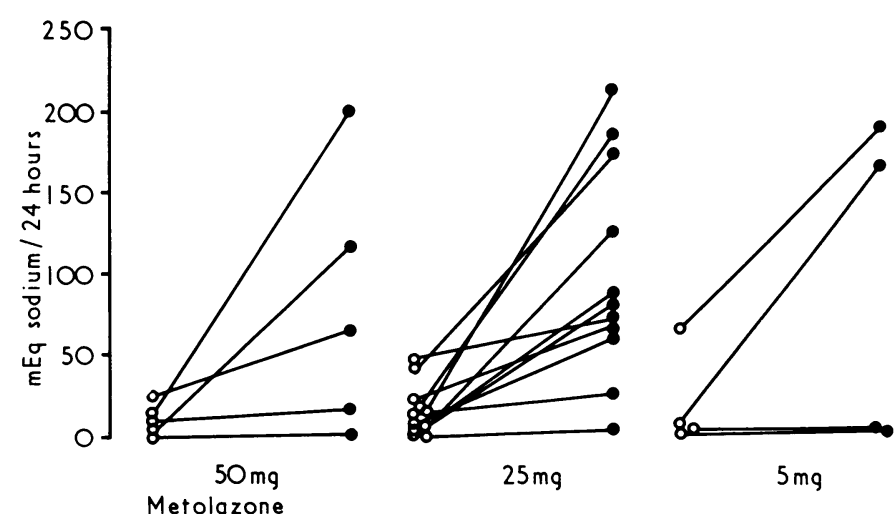

FIG. 1-Initial natriuretic response to metolazone: 24-hour urinary sodium in 20 patients. OMean baseline values. After first dose of metolazone. A similar maximal response occurred at all three dosage levels.

\section{ELECTROLYTE DISTURBANCES}

The criteria for abnormal serum electrolyte and urea levels are those used by Sherlock et al. (1966). They are as follows: 
TABLE II-Metolazone Trial: Clinical and Biochemical Abnormalities before and during Diuretic Therapy

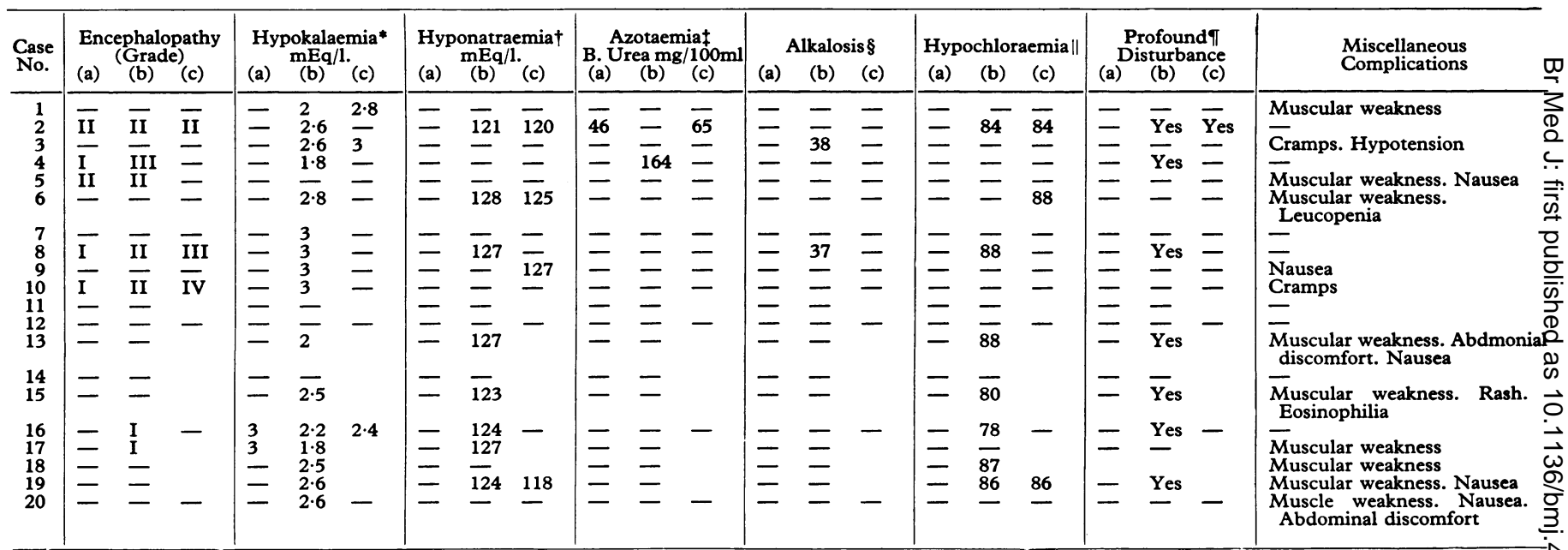

(a) Before diuretic therapy. (b) Metolazone. (c) Metolazone plus potassium-sparing diuretic.

-Serum potassium less than $3.1 \mathrm{mEq} / 1$.

Serum sodium less than $130 \mathrm{mEq} / \mathrm{l}$.

Blood urea greater than $40 \mathrm{mg} / 100 \mathrm{ml}$

\&Serum bicarbonate greater than $35 \mathrm{~m}$
i| Serum chloride less than $90 \mathrm{mEq} / 1$.

IISerum chloride less than $90 \mathrm{mEq} / 1$.

IAt least three serum electrolyte or urea abnor

sodium less than $130 \mathrm{mEq} / 1$., potassium less than $3.1 \mathrm{mEq} / 1$., chloride less than $90 \mathrm{mEq} / 1$., bicarbonate greater than 35 $\mathrm{mEq} / 1$, and urea greater than $40 \mathrm{mEq} / 1$. In all but three patients all the serum levels were on the normal side of these values before diuretic therapy was begun. The electrolyte disturbances which are described below occurred when patients were taking only metolazone.

\section{PROFOUND DISTURBANCE OF SERUM ELECTROLYTES AND UREA}

This is defined as a disiurbance involving three or more of the above values (Sherlock et al., 1966), and occurred in 7 of 20 patients (Table II). One of two patients (Cases 2 and 4) who died of gastrointestinal haemorrhage, renal failure, and hepatic coma came into this group; he was resistant to metolazone. Case 4 did not fulfil the criteria for inclusion in the group; she had a massive diuresis after only one 50-mg dose of metolazone, developed precoma and profound hypokalaemia, and as her renal failure progressed she developed hyperchloraemic acidosis.

A third patient (Case 8 ) had hyponatraemia, hypokalaemia, and a hypochloraemic alkalosis. She was withdrawn from the trial because of hepatic precoma and died three weeks later of a cardiac infarction. Case 13, with a hepatoma, had hypokalaemia, hyponatraemia, and hypochloraemia after a brisk diuresis. He died within six weeks.

Of the remaining three patients (Cases 15, 16, and 19), all of whom had hyponatraemia, hypokalaemia, and hypochloraemia, two (Cases 16 and 19) were resistant to metolazone but responded on addition of spironolactone, which also improved their electrolyte disturbance.

\section{HYPOKALAEMIA}

A serum potassium level of less than $3.1 \mathrm{mEq} / 1$. was the most common abnormality and occurred in 16 patients (Table II). Most were taking oral potassium chloride supplements (50-100 mEq daily) when diuretic therapy was started. Hypokalaemia often occurred despite administration of massive potassium chloride supplements (up to $230 \mathrm{mEq}$ daily). The potassium intake usually exceeded the urinary potassium level (Fig. 2).

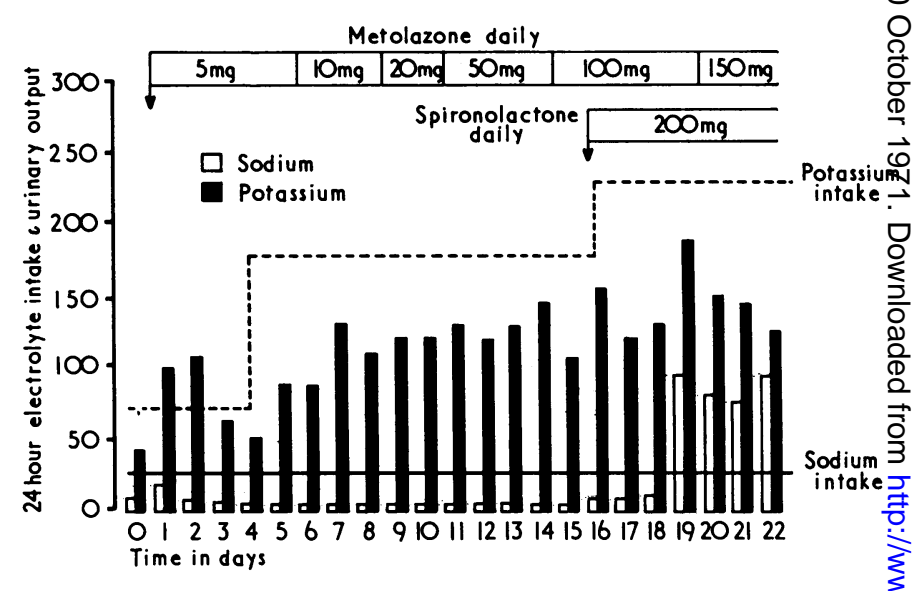

FIG. 2-24-hour sodium and potassium intake and urinary output during $\leqslant$ metolazone therapy in one patient. The blocks represent urinary sodiump and potassium. The dotted line represents approximate potassium intake the unbroken line represents sodium intake. Though urinary potassiumb levels are high, the intake of potassium is higher. Natriuresis did not occup during this period of kaliuresis. When spironolactone was added natriuresis ensued but there was no fall in the urinary potassium levels.

In four patients (Cases 2, 16, 19, and 20) hypokalaemia was associated with resistance to metolazone and was corso rected by the addition of amiloride or spironolactone.

\section{HYPONATRAEMIA}

Eight patients had a serum sodium level of less than $130 \mathrm{D}$ $\mathrm{mEq} / 1$. (Table II). Three of these (Cases 2, 16, and 19) hadp levels of less than $125 \mathrm{mEq} / 1$. at a time when they weres refractory to metolazone, and Case 2 remained resistant to all diuretic therapy after he was taken out of the trial. On\& patient (Case 19) with chronic active hepatitis was started on prednisolone for this condition and his serum sodium rose from 118 to $133 \mathrm{mEq} / 1$. in a few days (this was accompanied by a brisk diuresis). The remaining five patients (Cases $6,8,13,15$, and 17) developed hyponatraemia after a satisfactory diuresis. 


\section{HYPOCHLORAEMIC ALKALOSIS}

This complication occurred in only one patient (Case 8) and was part of a profound electrolyte disturbance. It was corrected by amiloride. Another patient (Case 3) had an alkalosis but no hypochloraemia.

\section{HYPOCHLORAEMIA}

Seven patients were hypochloraemic (Table II) and all were also hypokalaemic. The hypochloraemia was usually corrected by increasing the potassium chloride supplement. Betaine monohydrochloride was given to two patients (Cases 16 and 19).

\section{AZOTAEMIA}

Only one patient (Case 4) had this complication while taking only metolazone (Table II). She developed renal failure due to a combination of a massive diuresis and a gastrointestinal haemorrhage. Another patient (Case 2) was receiving a combination of metolazone with amiloride and had just had a gastrointestinal haemorrhage when azotaemia occurred. He was one of the two cases of resistance to a combination of metolazone with a potassium-sparing diuretic. He was taken out of the trial. Both patients died.

\section{HEPATIC ENCEPHALOPATHY}

Portal-systemic encephalopathy may be classified into four grades: grade I, confusion; grade II, drowsiness; Grade III, stupor; and grade IV, coma.

Seven patients developed clinical evidence of portal-systemic encephalopathy during diuretic therapy; five of them had had previous episodes of encephalopathy. In three of the seven patients encephalopathy was clearly precipitated by a diuresis, though only two (Cases 4 and 8 ) had a serum electrolyte disturbance (hypokalaemia) at the time. These two, both of whom had a profound electrolyte disturbance, developed precoma and another (Case 10) went into coma. One (Case 4) died of a gastrointestinal haemorrhage and renal failure. In Cases 8 and 10 the addition of amiloride worsened a pre-existing encephalopathy; in Case 10 coma was precipitated but it resolved when the diuretics were withdrawn.

Of the remaining four Case 2 had recurrent grade II encephalopathy, after gastrointestinal haemorrhage, and Cases 5 and 16 had grade I-II encephalopathy at a time when they were resistant to diuretics. Three of these patients were hypokalaemic and two of them had a profound electrolyte disturbance associated with resistance to diuretic therapy.

\section{MISCELLANEOUS COMPLICATIONS}

Eight patients complained of muscular weakness associated with hypokalaemia (Table II). Two (Cases 3 and 10) had muscle cramps and one of these was hypotensive; neither of them was hyponatraemic. Nausea occurred in five patients (Cases 5, 9, 13, 19, and 20) and abdominal discomfort in two (Cases 13 and 20). This may have been related to potassium supplements. One patient (Case 15) had a fever, a rash, and eosinophilia which rapidly subsided though he had continued taking metolazone. The white blood cell count in Case 6 fell from 4.500 to 1,500 while he was taking metolazone, amiloride, and nitrazepam. He had recently bled from oesophageal varices and had been given a blood transfusion. His diuretic regimen was altered to frusemide and spironolactone.

\section{Discussion}

The initial response to metolazone was good; in 14 of the 20 patients the 24-hour urinary sodium excretion increased by more than $25 \mathrm{mEq}$ (Fig. 1). The response was similar at all three initial dosage levels: $50 \mathrm{mg}, 25 \mathrm{mg}$, and $5 \mathrm{mg}$. This suggests that $5 \mathrm{mg}$ is a suitable starting dose.

Only eight patients were maintained on metolazone. The remainder required additional amiloride or spironolactone in order to correct hypokalaemia or, more often, to induce a diuresis (Table I). In 18 patients ascites was controlled with metolazone with or without a potassium-sparing diuretic. These results indicate that metolazone should usually be given together with a potassium-sparing diuretic.

The complications discussed below occurred when metolazone was used alone. The incidence of these complications is compared with that occurring in an aetiologically similar group of 112 patients studied by Sherlock et al. (1966) (Table III). A second study (Senewiratne and Sherlock, 1968) is also included for comparison though it differs from the above studies in that potassium supplements were omitted.

TABLE III-Percentage of Patients with Serum Electrolyte Changes, Azotaemia, Results of Sherlock et al. (1966) and Senewiratne and Sherlock (1968)

\begin{tabular}{|c|c|c|c|c|c|c|c|c|}
\hline Diuretic & 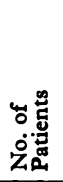 & 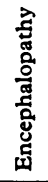 & 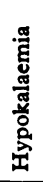 & 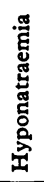 & 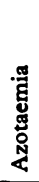 & 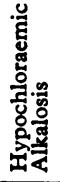 & 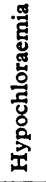 & 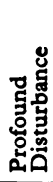 \\
\hline \multirow{4}{*}{$\begin{array}{l}\text { Metolazone } \\
\text { Chlorothiazide* } \\
\text { Chlorothiazide + } \\
\text { spironolactone* } \\
\text { Frusemide* } \\
\text { Frusemide + } \\
\text { amiloride† } \\
\text { Ethacrynic } \\
\text { acid* }\end{array}$} & $\begin{array}{l}20 \\
31\end{array}$ & $\begin{array}{l}35 \\
22\end{array}$ & $\begin{array}{l}80 \\
55\end{array}$ & $\begin{array}{l}40 \\
40\end{array}$ & $\begin{array}{r}5 \\
22\end{array}$ & $\begin{array}{l}5 \\
6\end{array}$ & $\begin{array}{l}35 \\
10\end{array}$ & $\begin{array}{l}35 \\
13\end{array}$ \\
\hline & $\begin{array}{l}39 \\
17\end{array}$ & $\begin{array}{l}28 \\
26\end{array}$ & $\begin{array}{l}16 \\
64\end{array}$ & $\begin{array}{l}49 \\
43\end{array}$ & $\begin{array}{l}31 \\
43\end{array}$ & $\begin{array}{l}0 \\
9\end{array}$ & $\begin{array}{l}13 \\
30\end{array}$ & $\begin{array}{l}15 \\
39\end{array}$ \\
\hline & 24 & 4 & 16 & 40 & 40 & 5 & 54 & \\
\hline & 16 & 53 & 50 & 56 & 56 & 59 & 69 & 59 \\
\hline
\end{tabular}

*Sherlock et al., 1966.

†Senewiratne and Sherlock (1968).

The long duration of action of metolazone (about 24 hours, increasing with higher doses of the drug) was inconvenient for some patients. However, it might be advantageous to have a more gradual diuresis and thereby a less rapid fall in the effective plasma volume and renal blood flow (Shear et al., 1970). In this connexion the low incidence of azotaemia (5\%) compared with the series of Sherlock et al. (1966) shown in Table III could be due to the gradual mode of action of metolazone.

Hypokalaemia was the commonest electrolyte disturbance in this study $(80 \%)$ and a higher incidence was noted than in previous studies (Table III). This occurred despite administration of large doses of potassium chloride supplements (up to $230 \mathrm{mEq} / 1$.) and might not have been due to potassium depletion, as the potassium intake often exceeded the urinary potassium level (Fig. 2). Hypokalaemia was usually corrected by amiloride or spironolactone and occurred in only 3 of the 12 patients who were taking a combination of metolazone with one of these drugs (Table II). This emphasizes the value of potassium-sparing diuretics.

Hyponatraemia occurred in $40 \%$ of patients, an incidence comparable to that in Sherlock's series (Table III). Hypochloraemic alkalosis (5\%) was rare, and this low incidence parallels that in Sherlock's series. Hypochloraemia (35\%) occurred more often than with some of the diuretics in the series of Sherlock et al. (1966) (Table III: chlorothiazide and frusemide), but frusemide with amiloride and ethacrynic acid used alone showed a higher incidence of hypochloraemia.

A profound electrolyte disturbance was seen in $35 \%$ of patients, and only frusemide and ethacrynic acid in the series of Sherlock et al. (1966) showed a higher incidence (Table 
III). Of the diuretics used in Sherlock's series frusemide most closely resembles metolazone in the pattern of electrolyte disturbance which is produced. Metolazone produces more electrolyte disturbance than the thiazides, and this suggests that it is a more powerful diuretic.

Encephalopathy occurred in $35 \%$ of patients compared with $22-28 \%$ in the series of Sherlock et al. (1966) in which thiazides (with or without spironolactone) and frusemide were used. In our study five of the seven patients with encephalonathy had hypokalaemia though this was associated with a diuresis in only three of them. Read et al. (1959) found a high incidence of hypokalaemia in relation to encephalopathy, but Sherlock et al. (1966) found that encephalopathy was related to electrolyte disturbance as a whole rather than to hypokalaemia per se. In the present series four out of seven patients with encephalopathy had a profound electrolyte disturbance, reflecting poor hepatocellular function as well as potent diuretic therapy (Hecker and Sherlock, 1956; Sherlock et al., 1966).

Miscellaneous complaints associated with diuretic therapy were common, especially muscle weakness, which was probably due to hypokalaemia. Nausea and abdominal discomfort could have been due to diuretic therapy or potassium supplements. Cramps and hypotension were associated with hyponatraemia after diuresis. One patient had a rash and eosinophilia; the relationship to diuretic therapy was uncertain as he had had several previous similar episodes. Similarly, the cause of leucopenia in one patient (Case 6) was uncertain; it may have been due to hypersplenism as the patient had pronounced splenomegaly and previous thrombocytopenia, or it could have been due to metolazone, amiloride, or nitrazepam.

Metolazone, therefore, has several major disadvantages: a $\stackrel{\varnothing}{\stackrel{2}{2}}$ high incidence of hypokalaemia $(80 \%)$, hypochloraemia $(35 \%)$,.. and encephalopathy $(35 \%)$. However, the low incidence of $\overrightarrow{\vec{F}}$ azotaemia $(5 \%)$ compared with previous series (Sherlock $\stackrel{9}{\circ}$ et al., 1966) suggests that it may be useful if renal function is greatly impaired.

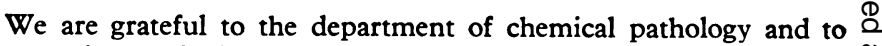
the nursing staff of the Royal Free Hospital for their help. One of us (P.H.) was in receipt of a Stanley Thomas Johnson Fellowship. This work was supported by the Pennwalt Corporation, Rochester, N.Y., U.S.A

\section{References}

Hecker, R., and Sherlock, S. (1956). Lancet, 2, 1121

Read, A. E., Haslam, R. M., Laidlaw, J., and Sherlock, S. (1959). N Clinical Science, 18, 409.

Senewiratne, B., and Sherlock, S. (1968). Lancet, 1, 120.

Shear, L., Ching, S., and Gabuzda, G. J. (1970). New England fournal 음 of Medicine, 282, 1391.

Sherlock, S., Senewiratne, B., Scott, A., and Walker, J. G. (1966). W Lancet, 1, 1049.

\title{
Some Operative and Postoperative Hazards of Legal Termination of Pregnancy
}

\author{
SATYA V. SOOD
}

British Medical fournal, 1971, 4, 270-273

\section{Summary}

Analysis of 1,317 patients admitted for N.H.S. abortion showed an overall morbidity of $16.8 \%$ excluding urinary tract infection. Genital infection, chest infection, reevacuation or perforation of the uterus, and haemorrhage were the more common complications. There was one maternal death.

\section{Introduction}

As a result of the Abortion Act of 1967 therapeutic abortion has become not only an accepted medical procedure, and the only medical procedure controlled by law, but also one of the commonest gynaecological operations. The demand for abortion is still rising. The annual numbers in our unit have shown a remarkable increase from 1960 to 1969 (Table I). The fall in 1970 was due to restriction on abortions owing to the long waiting lists for other gynaecological operations. The number of deliveries has not varied appreciably since 1963. Mortality reports vary enormously from one country to another (Table II).

The Annual Reports of the Chief Medical Officer (1970) indicates that mortality rates showing the highest risk of

\section{West Middlesex Hospital, Isleworth, Middlesex}

SATYA V. SOOD, F.R.C.S.ED., M.R.C.O.G., Senior Registrar in Obstetrics and Gynaecology death are among women aged 35 to 44 years, and also among women whose pregnancies were terminated by hysterotomy $(8 \cdot 4 / 10,000)$ or by hysterectomy $(12 \cdot 6 / 10,000)$. The fatality rate for evacuation of the uterus by aspiration is $2 \cdot 2 / 10,000$ and for all other methods, including dilatation and curettage, it is $0 \cdot 9 / 10,000$. Morbidity is inevitable even with a simple operation, and most methods used in termination of pregnancy are far from simple.

Published estimates of complications after therapeutic TABLE I-Number of Therapeutic Abortions and Deliveries in the West Middlesex Hospital

\begin{tabular}{|c|c|c|c|}
\hline \multicolumn{2}{|c|}{ Year } & No. of Abortions & No. of Deliveries \\
\hline $\begin{array}{l}1960 \\
1961 \\
1962 \\
1963 \\
1964 \\
1965 \\
1966 \\
1967 \\
1968 \\
1969 \\
1970\end{array}$ & $\begin{array}{l}. \\
\cdots \\
\cdots \\
\cdots \\
\cdots \\
\cdots \\
\cdots \\
\cdots \\
\cdots\end{array}$ & $\begin{array}{r}1 \\
7 \\
32 \\
32 \\
42 \\
88 \\
192 \\
286 \\
382 \\
468 \\
407\end{array}$ & $\begin{array}{l}1,899 \\
1,086 \\
2,126 \\
2,343 \\
2,549 \\
2,480 \\
2,600 \\
2,493 \\
2,346 \\
2,361 \\
2,468\end{array}$ \\
\hline
\end{tabular}

TABLE II-Mortality Due to Legal Abortion

\begin{tabular}{|c|c|c|c|c|}
\hline Country & Date & $\begin{array}{l}\text { No. of } \\
\text { Abortions }\end{array}$ & $\begin{array}{l}\text { No. of } \\
\text { Deaths }\end{array}$ & $\begin{array}{l}\text { Deaths } / 100,000 \\
\text { Abortions Performed }\end{array}$ \\
\hline $\begin{array}{ll}\text { Denmark } & \ldots \\
\text { Sweden } & \ldots \\
\text { Yugoslavia } & \ldots \\
\text { Japan } & \text {. } \\
\text { Czechoslovakia } \\
\text { Hungary }\end{array}$ & $\begin{array}{l}1961-5 \\
1960-6 \\
1960-1 \\
1959-65 \\
1958-64 \\
1963-4\end{array}$ & $\begin{array}{r}21,700 \\
30,600 \\
177,499 \\
6,860,000 \\
561,000 \\
328,200\end{array}$ & $\begin{array}{r}9 \\
12 \\
8 \\
278 \\
12 \\
2\end{array}$ & $\begin{array}{r}41.4 \\
39.2 \\
4.5 \\
4.1 \\
2.1 \\
0.6\end{array}$ \\
\hline
\end{tabular}

